\title{
SENI BERPIKIR KREATIF DALAM MATEMATIKA
}

\author{
Tri Nova Hasti Yunianta \\ Program Studi Pendidikan Matematika \\ Universitas Kristen Satya Wacana
}

\begin{abstract}
ABSTRAK
Mulai dari bangun tidur, seorang siswa memikirkan waktu akan berangkat sekolah, uang saku yang ia terima, biaya naik angkutan, harga makanan di kantin, rute jalan terpendek ketika pulang sekolah dan masih banyak lagi semua berkaitan dengan matematika. Akan tetapi masih banyak siswa yang belum mengerti dan menyadari manfaat matematika dalam kehidupan seharihari. Aktivitas matematika yang kreatif memberi ruang seseorang mencipta sesuatu melalui matematika dan membuat sesuatu yang kompleks menjadi sederhana serta menghasilkan gagasan yang luar biasa terhadap matematika. Inilah seni berpikir kreatif dalam matematika.
\end{abstract}

Kata Kunci: Seni, Berpikir Kreatif, Matematika

\section{PENDAHULUAN}

Anak-anak muda merupakan generasi penerus bangsa dan calon pengganti generasi tua saat ini. Generasi saat ini berkembang melalui bekal pendidikan yang telah diterima sebelumnya. Memperbaiki pendidikan pada generasi masa sekarang sama artinya dengan menyiapkan generasi muda agar mereka mendapatkan pengalaman belajar yang lebih baik sehingga mendukung mereka menyelesaikan masalah dalam kehidupan sehari-hari.

Matematika memiliki peran yang penting bagi kehidupan manusia. Mulai dari bangun tidur, seorang siswa memikirkan waktu akan berangkat sekolah, uang saku yang ia terima, biaya naik angkutan, harga makanan di kantin, rute jalan terpendek ketika pulang sekolah dan masih banyak lagi semua berkaitan dengan matematika. Akan tetapi masih banyak siswa yang belum mengerti manfaat matematika dalam kehidupan sehari-hari.

Matematika memang berisi konsepkonsep yang abstrak, tetapi konsep-konsep yang siswa pelajari hanya berhenti sebatas kajian pada teoritis saja. Oleh karena itu perlu adanya pembelajaran matematika yang benarbenar meningkatkan kemampuan siswa berpikir kreatif, kritis, logis dan analitis. Inilah seni dalam matematika yang memungkinkan kita untuk berpikir kreatif agar pembelajaran yang dituntut dalam tujuan pendidikan nasional tercapai khususnya pada mata pelajaran matematika. Seni berpikir kreatif dalam matematika tidak hanya berhenti pada konsepkonsep matematika yang abstrak, melainkan lebih pada penerapan, pengembangan dan penemuan ide matematika dalam kehidupan sehari-hari.

\section{TINJAUAN PUSTAKA}

\section{Kemampuan Berpikir Kreatif}

Potur \& Barkul (2009) mendefinisikan berpikir kreatif adalah sebuah kemampuan kognitif orisinil dan proses memecahkan masalah yang memungkinkan individu menggunakan intelegensinya dengan cara yang unik dan diarahkan menuju pada sebuah hasil. Kemampuan kognitif orisinil ini menekankan pada kemampuan kognitif seseorang untuk 
menciptakan sesuatu yang unik yang berbeda dengan apa yang dimiliki orang lain.

Kemampuan siswa dalam berpikir kreatif memungkinkan orang tersebut memperolah banyak cara atau alternatif penyelesaian dari suatu masalah. Meskipun terkadang terlalu banyak cara akan menyulitkan sampai kepada hasil akhir, namun dengan banyaknya pilihan akan memungkinkan siswa sampai kepada tujuan dibandingkan siswa yang memang benar-benar tidak memiliki cara untuk sampai kepada solusi masalahnya. Oleh karena itulah berpikir kreatif sangat penting dalam diri seorang siswa. Berpikir kreatif merupakan kunci dari berpikir untuk merancang, memecahkan masalah, untuk melakukan perubahan dan perbaikan, memperoleh gagasan baru (de Bono, 2007). Seorang pribadi yang kreatif mampu untuk memberikan kita suatu pemikiran baru atas permasalahan-permasalahan yang dia hadapi atau kita hadapi, baik yang berkaitan dengan kehidupan sehari-hari atau berkaitan dengan kajian-kajian praktikum (Al-Khalili,
2005: 30). Melalui berpikir kreatif siswa diharapkan juga dapat menyelesaikan masalahnya dalam kehidupan sehari-hari secara kreatif.

Adapun aspek-aspek kemampuan berpikir kreatif yang dapat dilihat yaitu kelancaran, keluwesan, keaslian, elaborasi, dan sensitivitas (Munandar, 2009; Evans, 1994; Mann, 2005). Melalui aspek-aspek tersebut berpikir kreatif dapat diukur ketercapaiannya dengan mengidentifikasi melalui pertanyaan terbuka (Mahmudi, 2010).

Oleh karena itu kemampuan berpikir kreatif dapat diukur berdasarkan tingkat kelancaran, keluwesan, orisinalitas, elaborasi dan sensitivitas dari siswa. Hal ini yang akan menjadi aspek-aspek penting pengukuran di dalam penyusunan instrumen penelitian untuk mengukur kemampuan berpikir kreatif siswa. Pada Tabel 1 disajikan tentang perilaku berpikir kreatif dan artinya menurut aspekaspek yang diukur.

Seseorang yang memiliki kemampuan berpikir kreatif yang baik yaitu memiliki

Tabel 1. Perilaku berpikir kreatif dan artinya menurut aspek-aspek yang diukur

\begin{tabular}{|c|c|c|}
\hline No. & $\begin{array}{c}\text { Perilaku Berpikir } \\
\text { kreatif }\end{array}$ & Arti \\
\hline 1. & $\begin{array}{l}\text { Berpikir lancer } \\
\text { (fluency) }\end{array}$ & $\begin{array}{l}\text { - } \quad \text { menghasilkan banyak gagasan/jawaban yang relevan, } \\
\text { - arus pemikiran lancer }\end{array}$ \\
\hline 2. & $\begin{array}{l}\text { Berpikir luwes } \\
\text { (fleksibel) }\end{array}$ & $\begin{array}{l}\text { - } \quad \text { menghasilkan gagasan-gagasan yang beragam } \\
\text { - } \quad \text { mampu mengubah cara atau pendekatan } \\
\text { - } \quad \text { arah pemikiran yang berbeda }\end{array}$ \\
\hline 3. & $\begin{array}{l}\text { Berpikir orisinil } \\
\text { (originality) }\end{array}$ & $\begin{array}{l}\text { - memberikan jawaban yang tidak lazim, yang lain dari yang lain, yang } \\
\text { jarang diberikan kebanyakan orang. }\end{array}$ \\
\hline 4. & $\begin{array}{l}\text { Berpikir terperinci } \\
\text { (elaborasi) }\end{array}$ & $\begin{array}{l}\text { - } \quad \text { mengembangkan, menambah, memperkaya suatu gagasan } \\
\text { - } \quad \text { memperinci detail-detail } \\
\text { - memperluas suatu gagasan }\end{array}$ \\
\hline 5. & $\begin{array}{l}\text { Sensitivitas } \\
\text { (Sensitivity) }\end{array}$ & $\begin{array}{l}\text { - } \quad \text { kepekaan terhadap masalah } \\
\text { - } \text { memiliki kepekaan terhadap langkah-langkah jawaban yang } \\
\text { mengarah kepada tujuan/hasil akhir }\end{array}$ \\
\hline
\end{tabular}

Sumber: Munandar (2009); Evans (1994) 
keseimbangan yang baik dari kelima aspek berpikir kreatif. Berdasarkan penelitian di salah satu SMP di kabupaten Pati, berpikir luwes memiliki nilai paling rendah yang dimiliki oleh siswa SMP, tetapi siswa ini memiliki nilai sensitivitas yang tinggi (Yunianta dkk, 2012). Siswa cenderung sensitif tetapi agak sulit berubah karena tidak luwes dalam berpikir. Hal ini perlu mendapat perhatian dari para pendidik, khususnya guru. Guru perlu mengembangkan seni berpikir kreatif dalam matematika agar kemampuan-kemampuan dalam diri siswa berkembang secara optimal. Stigma bahwa matematika sulit juga diharapkan dapat direduksi.

\section{Seni Berpikir Kreatif dalam Matematika}

Seni dalam Kamus Besar Bahasa Indonesia adalah kesanggupan awal untuk menciptakan sesuatu yang bernilai tinggi (luar biasa). Seni berpikir kreatif dapat diartikan sebagai kesanggupan seseorang melalui kemampuan kognitifnya yang unik untuk menciptakan sesuatu yang luar biasa. Oleh karena itu, seni berpikir kreatif dalam matematika merupakan kesanggupan seseorang melalui kemampuan kognitifnya yang unik untuk menciptakan sesauatu yang luar biasa terhadap matematika. Seni berpikir kreatif dalam matematika sudah sejak lama digunakan oleh orang-orang yang menekuni bidang matematika.

Sama halnya dengan seni tari, seni musik maupun seni lukis, itu semua membutuhkan latihan terus menerus agar seseorang memiliki jiwa seni tersebut. Ada yang mengatakan bahwa saya tidak memiliki bakat musik sehingga saya tidak bisa seni musik. Munandar (2009) menyatakan bahwa anak berbakat adalah mereka yang oleh orangorang profesional diidentifikasi sebagai anak yang mampu mencapai prestasi tinggi karena mempunyai kemampuan-kemampuan unggul. Melihat ada atau tidaknya bakat juga dapat dilihat melalui kecepatan dan ketepatan seseorang dalam melakukan sesuatu dibandingkan orang lain yang mencoba dalam waktu yang sama dan dengan latihan yang sama pula.

Anak-anak berbakat memiliki kesempatan yang besar untuk mengembangkan seni berpikir kreatif ini khususnya dalam matematika. Seni berpikir kreatif dalam matematika ini juga perlu dikembangkan oleh guru maupun calon guru matematika. Jika guruguru matematika dapat mempraktikkan halhal yang kreatif dalam matematika, maka siswa akan terdorong untuk menggunakan kemampuan kognitifnya yang unik untuk menciptakan sesuatu yang unik terhadap matematika bahkan penyelesaian masalah matematika dalam kehidupan sehari-hari.

Matematika tidak hanya terbatas tentang angka dan lambang tetapi matematika juga memuat proses yang di dalamnya terdapat aktivitas mental. Susan Shcraton (2004) lewat penelitiannya terhadap siswa SD kelas dua melihat bahwa siswa ini memiliki cara yang unik untuk menemukan jawabannya.

Siswa ini memiliki cara yang unik menyelesaikan masalahnya. Hal ini dapat dikatakan bahwa siswa ini menggunakan seni berpikir kreatif dalam menyelesaikan masalah matematika. Banyak hal yang dapat dieksplorasi dari materi matematika. Sekali lagi seni berpikir kreatif tidak dalam matematika datang tiba-tiba. Seni ini perlu dipelajari dan dilatih agar guru atau calon guru mengerti dan dapat menguasai seni berpikir kreatif ini.

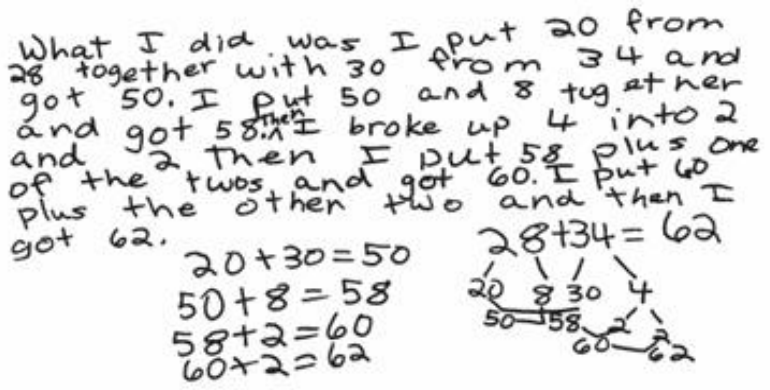

Gambar 1. Gambar cara seorang siswa SD kelas 2 menyelesaikan penjumlahan sepasang angka dua digit (Diadaptasi dari Scharton, 2004) 
Sebagai seorang guru atau calon guru sebelum mengajarkan matematika, perlu mengetahui kegunaan matematika dalam kehidupan sehari-hari. Jika seorang guru atau calon guru mengajarkan tentang suatu konsep matematika yang tidak memberikan contoh sebanyak-banyaknya manfaat konsep tersebut secara kreatif maka siswa akan terjebak pada konsep matematika yang stagnan. Konsep itu akan berhenti pada kemampuan kognitif siswa. Siswa perlu diajarkan cara penerapan, mengembangkan dan menemukan ide-ide yang unik lewat matematika. Selain itu konsepkonsep matematika yang abstrak juga memungkinkan untuk dapat dibuat ke dalam bentuk visualisasi, simulasi ataupun dipraktikkan ke dalam dunia nyata secara kreatif.

Berikut ini adalah beberapa konsep matematika yang dapat divisualisasikan kepada siswa secara kreatif yaitu: Penemuan konsep Keliling Persegi Panjang adalah panjang + lebar + panjang + lebar. Ada yang menulis, bahwa keliling persegi panjang adalah $2 \mathrm{x}$ panjang $+2 \times$ lebar. Bagaimana jika siswa menuliskan bahwa keliling persegi panjang adalah sisi + sisi + sisi + sisi? Bagi seseorang yang belum mengetahui rumus keliling persegi panjang hal ini tidak menjadi hal yang serius untuk disalahkan. Jika seorang anak mampu mendiferensiasi kemampuan kognitifnya maka ia akan dapat menerima bahwa persegi panjang memiliki dua sisi yang berbeda. Sisi yang panjang biasa disebut panjang dan sisi yang pendek biasa disebut lebar. Matematika bermula dari kesepakatan. Jika itu disepakati oleh orang tersebut maka penyebutan itu tidak akan menjadi masalah. Penerapan matematika secara kaku akan membuat masalah bagi siswa. Misalkan siswa sedang mengukur pekarangan taman sekolah mereka. Hanya saja mereka mendapatkan bentuk bangun yang tidak seperti persegi panjang.

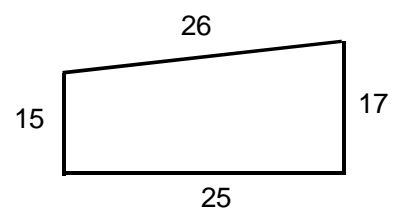

Gambar 2. Bentuk dan ukuran suatu Taman Sekolah

Masalah yang mereka hadapi terkadang tidak seperti apa yang mereka pelajari. Inilah kesempatan matematika berperan penting untuk menyelesaikan masalah siswa. Ketika seorang siswa memperoleh kesimpulan bahwa keliling persegi panjang adalah sisi + sisi + sisi + sisi, sebenarnya dia telah menemukan konsep memperoleh keliling segiempat. Mereka akan dapat menghitung keliling taman sekolah mereka.

Selanjutnya jika mereka hendak menghitung luas taman tersebut maka mereka juga perlu melihat bentuk bangun apa taman itu. Nampak pada Gambar 2 terlihat bangun yang tersebut adalah bangun trapesium. Mencari luas dapat menggunakan rumus luas trapesium atau dapat menggunakan luas segitiga.

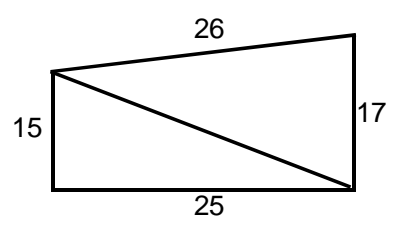

Gambar 3. Bentuk dan ukuran suatu Taman Sekolah dengan membaginya menjadi dua

Luas taman menggunakan rumus trapesium

$$
\frac{1}{2} \times(150+170) \times 250=40.000 \mathrm{~cm}^{2}
$$

Luas taman menggunakan pendekatan luas segitiga

$$
\left(\frac{1}{2} \times 150 \times 250\right)+\left(\frac{1}{2} \times 170 \times 250\right)=40.000 \mathrm{~cm}^{2}
$$

Contoh lain dari bentuk seni berpikir kreatif dalam matematika, yaitu tentang menemukan rumus luas trapesium menggunakan pendekatan luas persegi panjang. Caranya dengan mentransformasi trapesium menjadi persegi panjang. 


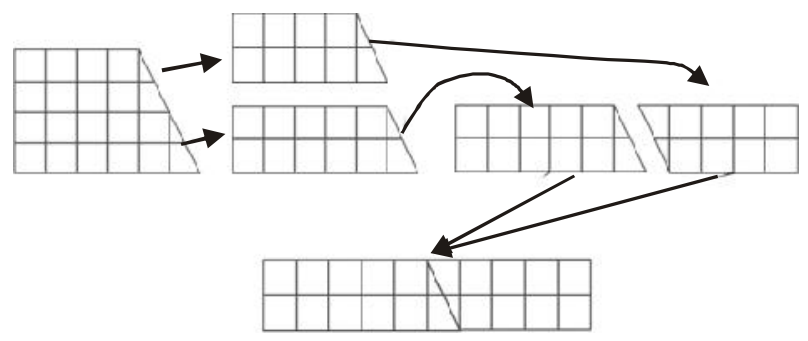

Gambar 4. Tranformasi trapesium menjadi persegi panjang

Selain itu, rumus luas trapesium dapat ditemukan menggunakan pendekatan yang lain. Salah satunya ketika siswa sudah memiliki pengetahuan tentang jajar genjang, luas trapesium dapat ditentukan melalui pendekatan luas jajar genjang.

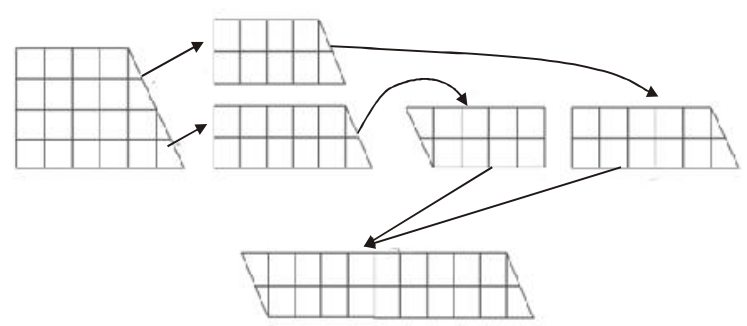

Gambar 5.Transformasi Trapesium menjadi jajar genjang

Luas trapesium = luas jajar genjang. Tinggi jajar genjang = 1/2 tinggi trapesium, dan alas jajar genjang = jumlah sisi sejajar trapesium. Oleh karena itu diperoleh luas trapesium = jumlah sisi yang sejajar $\times \frac{1}{2} \times$ tinggi.

Selanjutnya, Gambar 6 merupakan sebuah ilustrasi untuk menanamkan konsep bahwa volum kerucut adalah "satu per tiga" dari volum tabung dengan tinggi dan luas alas yang sama dengan kerucut.

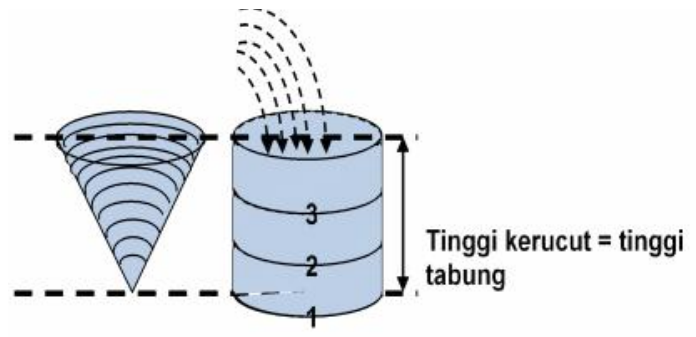

Diameter kerucut $=$ diameter tabung

Gambar 6. Kerucut dan Tabung dengan luas alas dan tinggi yang sama
Melalui ekperimen singkat guru dalam menanamkan konsep matematika melalui cara yang kreatif. Percobaan ini dapat dilanjutkan dengan membuat kondisi yang berbeda. Salah satunya dengan membuat tinggi kerucut setengah dari tinggi tabung dan seterusnya. Rasa ingin tahu siswa akan bertambah demikian juga pemikiran kreatif guru dapat ditransfer kepada siswa. Selain itu konsep matematika ini juga memungkinkan bentuk yang lain dieksplorasi menghasilkan ekperimen dan penemuan yang kreatif baik oleh guru atau siswa dalam pembelajaran seperti pada Gambar 7 dan Gambar 8.

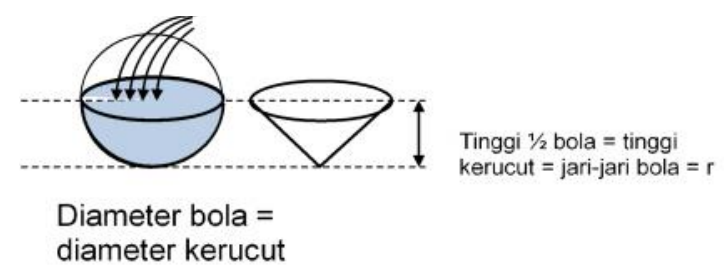

Gambar 7.Bola dan Kerucut dengan diameter yang sama dan tinggi kerucut sama dengan jari-jari bola

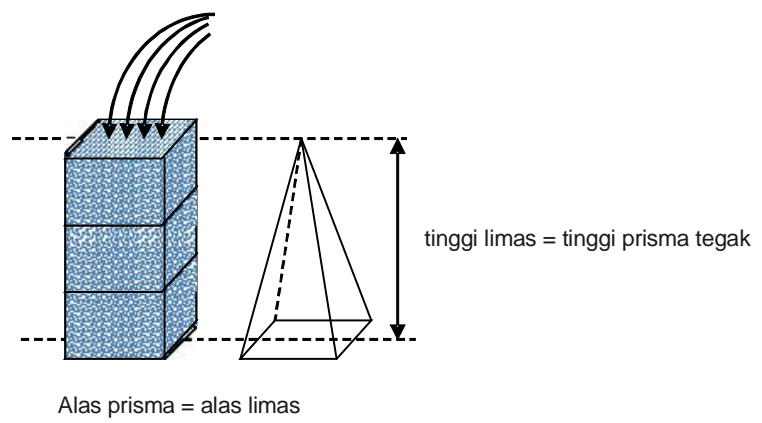

Gambar 8.Prisma dan Limas segi empat dengan luas alas dan tinggi yang sama

Salah satu proposisi yang luar biasa oleh Euclid dituliskan pada Buku II tentang The Element proposisi yang kedua menyatakan bahwa "If a straight line is divided into any two parts, the square on the whole line is equal to the sum of the squares on the two parts together with twice the rectangle contained by the two parts" (Eves, 1964: 64-65). Diperoleh identitas secara geometris yaitu: Salah satu proposisi yang luar biasa oleh Euclid dituliskan 
pada Buku II tentang The Element proposisi yang kedua menyatakan bahwa "If a straight line is divided into any two parts, the square on the whole line is equal to the sum of the squares on the two parts together with twice the rectangle contained by the two parts" (Eves, 1964: 64-65). Diperoleh identitas secara geometris yaitu: $(a+b)^{2}=a^{2}+2 a b+b^{2}$

Euclid dalam buku-bukunya menulis proposisi-proposisi yang sampai sekarang masih relevan dan banyak digunakan meskipun sekarang telah banyak berkembang cabang geometri lain selain geometri Euclid. Euclid mempraktikkan dan menuliskan hasil pemikiran yang luar biasa dan secara kreatif menemukan proposisi dan teorema-teorema yang luar biasa. Seni berpikir kreatif dalam matematika ini berkembang sejalan dengan aktivitas kreatif yang dilakukan oleh setiap orang dalam mempelajari matematika.

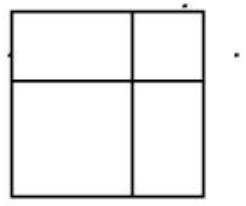

Secara kreatif Pascal mengembangkan dari sifat-sifat segitiga dan karena penerapanpene-rapan yang mana membuat sifat-sifat ini tersusun dengan baik yang dikenal dengan Segitiga Pascal (Eves, 1964: 260). Ia menemukan koefisien binomial yang digunakan pada segitiganya. Meskipun Pascal bukan orang pertama yang memulai penemuan ini, sebab ia melihat referensi dari seorang yang ahli aljabar dari Cina, Chu Shi-kie yang telah dikerjakan pada tahun 1303. Keingintahuan Pascal mengenai koefisien binomial menuntun Pascal menemukan Segitiga Pascal. Samuel Johnson (Oslon, 1992: 271) menyatakan bahwa keingintahuan adalah salah satu karakteristik yang paling permanen dan pasti dari pikiran hebat. Para ahli matematika melalui keingintahuan, mereka mendapatkan teorema, konsep dan prinsip matematika yang luar biasa.
Demikian halnya dalam penerapannya, matematika saat ini memiliki peran yang luar biasa, hanya saja banyak orang yang tidak menyadarinya.

Seni berpikir kreatif dalam matematika ini dapat berkembang dan terus berkembang sesuai dengan penemuan-penemuan dan perkembangan jaman. Matematika sekarang telah berkembang sangat pesat dan penerapannya digunakan dalam berbagai bidang kehidupan. Baik dalam sektor industri, perdagangan, administrasi dan masih banyak bidang lainnya. Oleh karena itu mengembangkan seni ini diperlukan oleh seorang guru atau calon guru khususnya, sebab kemampuan ini akan diwariskan kepada generasi bangsa ini melalui pembelajaran di dalam kelas. Guru yang kreatif akan membuat siswa termotivasi menjadi kreatif. Bagi seorang matematikawan juga sangat perlu mengembangkan seni berpikir kreatif dalam matematika guna mendapatkan inovasi-inovasi yang baru dalam kehidupan sehari-hari. Hal ini menjadikan ilmu pengetahuan akan berkembang dengan pesat. Meskipun demikian, perkembangan ilmu yang pesat tanpa disertai karakter individu yang baik akan dapat menuntun manusia ke dalam kehancuran.

\section{KESIMPULAN}

Aktivitas matematika yang kreatif memberi ruang seseorang mencipta sesuatu melalui matematika dan membuat sesuatu yang kompleks menjadi sederhana serta menghasilkan gagasan yang luar biasa terhadap matematika. Inilah seni berpikir kreatif dalam matematika. Kemampuan ini tidak dimiliki seseorang secara alami, melainkan memerlukan proses, ketekunan dan proses kreatif di dalamnya. Seni berpikir kreatif ini menjadikan seseorang bebas mengekspresikan kemampuan matematikanya dalam menyelesaikan masalah matematika yang dihadapi secara unik. Seorang guru perlu mengembangkan seni 
berpikir kreatif dalam matematika agar siswa yang diajar dapat secara alami belajar berpikir kreatif dalam menyelesaikan masalah matematikanya. Demikian juga matematika-wan perlu mengembangkan seni berpikir kreatif ini untuk mencipta inovasi-inovasi melalui matematika.

\section{DAFTAR PUSTAKA}

Al-Khalili, A. A. 2005. Mengembangkan Kreativitas Anak. Jakarta: Pustaka AlKautsar.

de Bono, E. 2007. Revolusi Berpikir. Bandung: Kaifa.

Evans, J. R. 1994. Berpikir Kreatif dalam Pengambilan Keputusan dan Manajemen. Jakarta: Bumi Aksara.

Eves, Howard. 1964. An Introduction to the History of mathematics. United States of America: Holt, Rinehart and Winston Inc.

Mahmudi, A. 2010. "Mengukur Kemampuan Berpikir Kreatif Matematis". Makalah. Konferensi Nasional Matematika XV UNIMA Manado, 30 Juni - 3 Juli 2010.

Mann, E. L. 2005. Mathematical Creativity and School Mathematics: Indicators of Mathematical Creativity in Middle School Students. Dissertation. University of Connecticut.
Munandar, U. 2009. Pengembangan Kreativitas Anak Berbakat. Penerbit Rineka Cipta: Jakarta.

Oslon, R. W. 1992. Seni Berpikir Kreatif. Jakarta: Erlangga

Potur, A. A. \& O. Barkul. 2009. Gender and creative thinking in education: Atheoretical and experimental overview. Journal, 6 (2), 44-57. http://www.az. itu.edu.tr/azv6n2 web/05poturbarku 10602.pdf (diunduh 14 Desember 2011).

Scharton, S. 2004. I did it my way: Providing opportunities for students to create, explain, and analyze computation procedures. Teaching Children Mathematic, 10, 278-283.

Yunianta, T. N. H., Rusilowati, A., \& Rochmad. 2012. Kemampuan Berpikir Kreatif Siswa pada pembelajaran Matematika Project-Based Learning dengan Peer and Self Assessment untuk Materi Segiempat Kelas VII SMPN RSBI di Kabupaten Pati. Prosiding Seminar Nasional Matematika dan Pendidikan Matematika. Yogyakarta: Universitas Negeri Yogyakarta. 